ceiling to the price at which fossil fuels can be sold for power production in the seventies.

The projections in the report are based on the assumption that the industrial production of the O.E.C.D. area will continue to grow without significant interruption. The demand for energy will march in step. It is expected that total consumption in the O.E.C.D. area will increase from the equivalent of 2,200 million tons of oil (in 1964) to 4,300 million tons of oil by 1980 . One novel feature of these forward estimates, however, is a levelling tendency, for the rate of increase of demand is expected to be smallest in those countries in which energy is at present used most intensivelyprincipally the United States. By 1980 it is reckoned that the United States will account for 60 per cent of the demand for energy within O.E.C.D., Europe for 30 per cent and Japan for the remaining 10 per cent. The total demand for energy in Eastern Europe and the Chinese Republic is expected to amount to 2,800 million tons of oil equivalent in 1980 , or roughly 65 per cent of the then demand within O.E.C.D. The corresponding ratio in 1960 was roughly 51 per cent.

The forward projections for nuclear energy are more optimistic than previous forecasts by the O.E.C.D. By the mid-eighties nuclear power may account for 35 per cent of all electricity production in North America, and as much as 40 per cent in Europe. Then natural gas from the North Sea suggests at least the possibility that what has already happened in North America may also happen in Europe. The report says that this is an exciting prospect, and then goes on to suggest how individual nations should frame their policies so as to take advantage of the flexibility provided by a diversity of sources of supply. In passing, even the operators of coalfields can glean some comfort, for there is a solemn passage about the great size of the reserves of fossil fuel. This is a report to please everybody.

\section{Who Needs Support?}

Lrke foundations elsewhere, the Alfred P. Sloan Foundation of New York is hard at work trying to devise ways of keeping ahead of government support for science and for education. In his report for 1965 , the President of the Foundation, Mr. Everett Case, says that the increased support from the U.S. Federal Government for scientific research at the universities and for students at college "has involved it in fields once largely the province of private initiative". Pointing to the scale on which the U.S. Government is at present supporting scientific research and education, Mr. Case says that "it is futile for private philanthropy to compete against the government". The report says that the federal government has not yet taken to supporting undergraduates and scientists in the carly stages of their careers in precisely the way in which the foundation is anxious to do so, but clearly Mr. Case thinks it is only a matter of time before the government catches up. He is evidently hoping that a systematic appraisal of the outcome of the Foundation's grants in recent years may make possible an objective review of foundation policy, and then throw up suggestions of new fields for philanthropy to conquer.

Grants worth \$13 million were awarded in 1965 , mostly in scientific research and education. The Sloan-Kettering Tnstitute is still high on the list of beneficiaries. The Foundation also seems to derive continued pleasure from open-ended grant-giving. Thus it has given $\$ 5$ million to Stanford University as an expendable fund for research in the physical sciences, and has continued the programme by which university scientists, usually at the post-doctoral stage, are awarded fellowships detached from particular programmes of research. This is in line with the Foundation's view that too rigid a link between university research and the award of grants and contracts from outside may interfere with academic freedom. The Foundation also allocated $\$ 500,000$ during 1965 to an imaginative scheme for supporting Negro male students at ten predominantly Negro colleges in the United States. The foundation stands out by its willingness to support schemes for the popularization of science, and is supporting the Scientists' Institute for Public Information and also the work of the Council for the Advancement of Science Writing in running training courses in science journalism.

\section{Smithsonian 1965}

The annual report of the Smithsonian Institution for the year ended June 30, 1965, shows an appropriation of $\$ 15.54$ million, of which $\$ 5.84$ million was for the United States National Museum, $\$ 1.25$ million for the Astrophysical Observatory, $\$ 319,601$ for the National Air Museum, $\$ 179,640$ for the Canal Zone Biological Area, $\$ 114,648$ for the Bureau of American Ethnology, and $\$ 113,330$ for the International Exchange Service. In his covering statement the Secretary, Dr. S. Dillon Ripley, refers to the establishment of an Office of Special Projects on the bicentenary of the birth of James Smithson, the founder, and says that one of the objects of that office is to examine the nature of knowledge and creative discovery as understood to-day.

The Muscum of Natural History had a busy year. Members of its staff discovered the presence on Dominica of the snail Planolina glabrata (Say), the intermediate host of schistosomiasis. The close relation between agave and yucca has been proved beyond doubt in a study of yucca moths. An ancient connexion has been found between the fauna of Repa (in the midPacific) and those of Australia, New Zealand and South Africa, and preliminary research in the Valley of Oaxaca, Southern Mexico, has verified the presence in many caves and rock shelters of abundant perishable remains of human occupation and shown that the corn cobs, cactus fruits and other associated artefacts came from the period $6500-2500$ B.c.

The Radiation Biology Laboratory has developed instruments to measure the spectral quality of sunlight, in $100 \mathrm{~m} \mu$ bands, from sunrise to sunset throughout the year. Further information was acquired on the chemical structure of polyphosphate compounds in marine organisms and algae. The Prairie network of automatic cameras for the simultaneous photography of very bright meteors went into full operation and the sensitivity and accuracy of the Harvard-Smithsonian Meteor Radar Network has been improved. New measurements have been made of radioactive and stable isotopes in meteorites and in dust samples from the Grecnland Icecap and elsewhere.

\section{Drop More Names}

Have the bad old days when it was only possible to get on by knowing the right people gone for good ? 